Printed in Great Britain

\title{
THE OCCURRENCE OF MYTILICOL $A$ INTESTINALIS STEUER, AN INTESTINAL COPEPOD PARASITE OF MYTILUS, IN THE SOUTH-WEST OF ENGLAND
}

\author{
J. T. DAVEY AND J. M. GEE \\ NERC Institute for Marine Environmental Research, Citadel Road, Plymouth PL1 3DH
}

(Figs. 1-4)

\begin{abstract}
The occurrence of Mytilicola intestinalis in populations of mussels in south-west England is recorded and compared with previous data. Since 1955 there have been two main changes in the distribution of Mytilicola: (a) it has invaded all the major estuarine mussel populations on the Bristol Channel coast, and (b) many previously uninfested open-coast populations all round the peninsula are now lightly infested. It is suggested that differences in infestation levels between estuarine and open-coast populations of mussels are due primarily to differences in the degree of exposure to wave action although factors such as size, population density and location of the hosts also influence infestation. The chance of the establishment of breeding pairs of Mytilicola depends on the parasite population size and its distribution through the host population.
\end{abstract}

\section{INTRODUCTION}

Mytilicola intestinalis Steuer is a copepod parasite found in the digestive tract of Mytilus sp. and occasionally other marine lamellibranchs (Hepper, 1953). The conclusions of Korringa (1951), Cole \& Savage (1951), Couteaux-Bargeton (1953), Meyer \& Mann (1950) and others on the relationship between the presence of Mytilicola and the collapse of the Dutch mussel fishery in 1950 led to the general conclusion that the parasite was a dangerous pest of shellfish. This stimulated a search for the parasite in Britain and in the mid-1950s it was found to be present in many mussel populations on the south coast of England and Wales (Hockley, 1951; Waugh, 1954; Hepper, 1955) with the exception of the south coast of the Bristol Channel (Bolster, 1954). No reappraisal of the extent and intensity of infestation by Mytilicola in the populations of mussels in the south west has been made since that time. For this reason a survey, designed initially to discover infested and uninfested populations of mussels near Plymouth for studies of host and parasite interaction, was extended to cover all the coast of Devon and Cornwall. Recent surveys in other parts of Britain (Drinkwater, 1971; Crowley, 1972; Dare, 1974) have indicated that there has been little change in parasite distribution limits and population size since 1950.

\section{METHODS}

The sampling sites shown in Fig. 1 were chosen, where possible, to coincide with those of previous workers (Hockley, 1951; Bolster, 1954; Hepper, 1955). At each site a minimum of 20 mussels over $20 \mathrm{~mm}$ in length was collected, unless it was not possible to find this number during a search lasting approximately $30 \mathrm{~min}$. At the same time a note was made of $(a)$ the general exposure 
of the site (in the sense of Ballantine, 1961), (b) the position of the mussel bed in relation to tidal height, raised surfaces and any unusual features such as a warm water outlet, and $(c)$ host population density based on the time taken to collect 20 mussels.

Mussels were brought back to the laboratory dry and transferred to holding tanks in a recirculating sea-water system or to bowls of aerated sea water. Examination was completed within 4 days and usually within 1 or 2 days. Mussels were measured to the nearest $0.5 \mathrm{~mm}$, the digestive tract opened and any Mytilicola counted and removed to $5 \%$ formol saline before being measured and sexed.

On a transect up the beach at Beggar's Island, Lynher River, samples of mussels were collected at low water and every $10 \mathrm{~m}$ up the beach to the upper limit of the mussel zone. The height above Chart Datum of low water was taken from the Navy Hydrographer's Tide Gauge at Devonport, and the height of each sample above low water was determined.

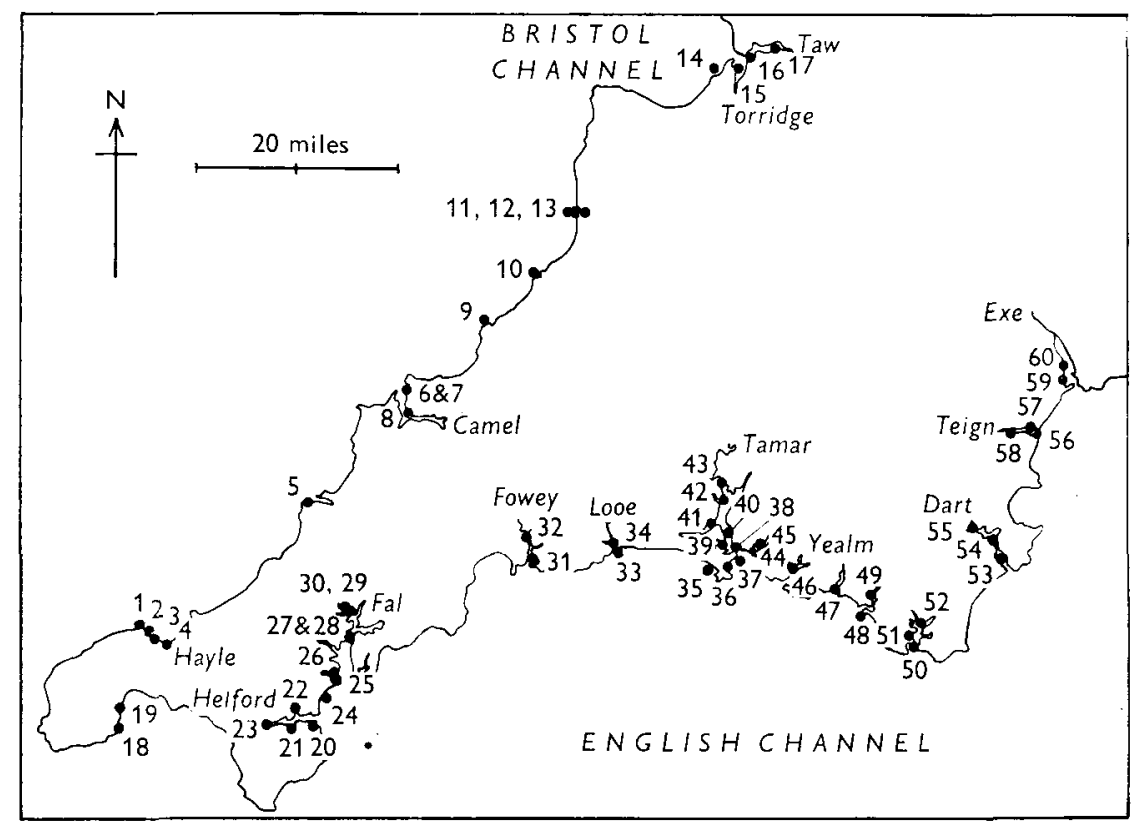

Fig. 1. Sites fron which samples of mussels were obtained.

\section{RESULTS}

Table 1 , in which the sites are arranged in order of increasing mean number of parasites per host, gives the data on host size and parasite burden for each sample as well as information on location and density of the host population from which the samples were taken. The number in parentheses after each site name is a cross-reference to Fig. 1.

In Table 2, published data of earlier authors have been tabulated alongside data from the present survey for either the same or adjacent sites. As earlier authors have not always expressed their results in the same form, the data have to be compared on the basis of either percentage infestation or mean number of parasites per host. 


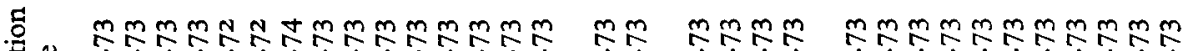

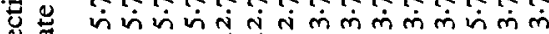
용

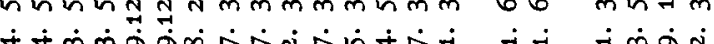

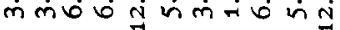

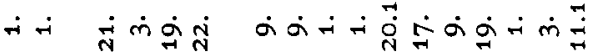

戛

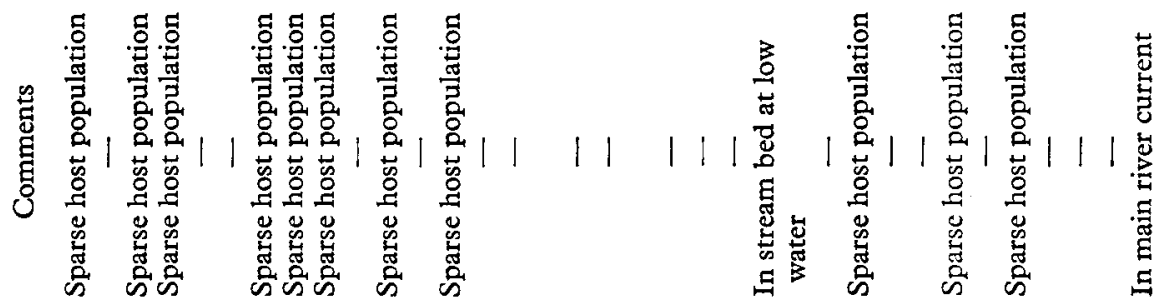
密

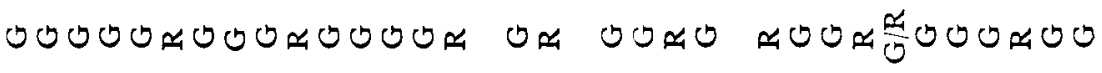

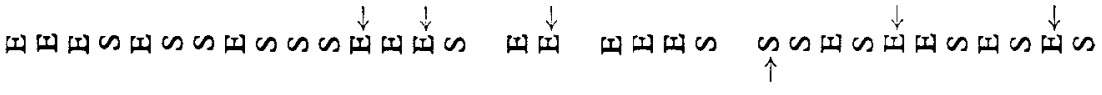
总富。

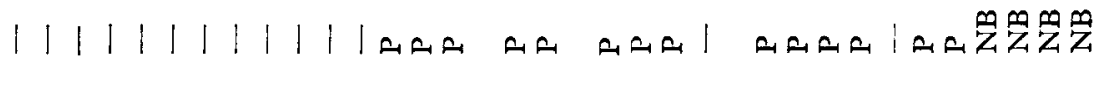

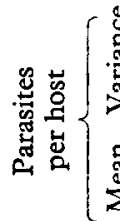

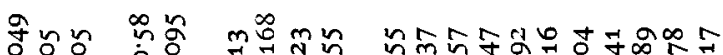
000000000000000 0ं

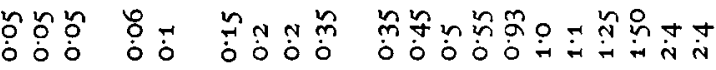

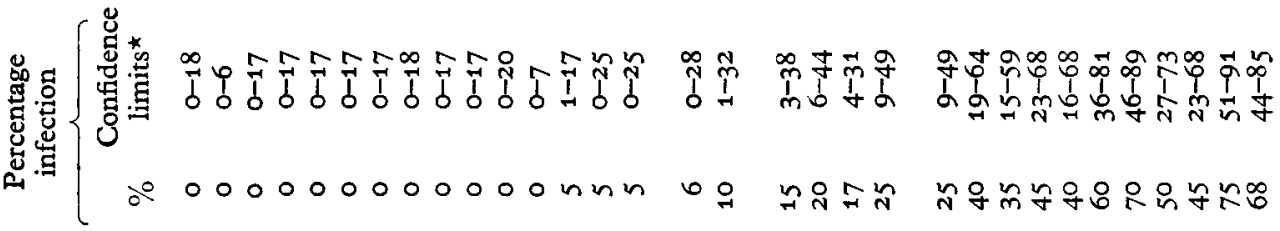

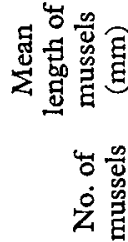

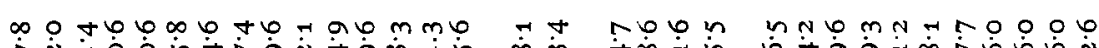

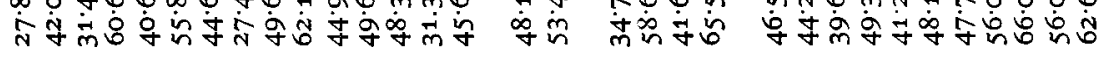

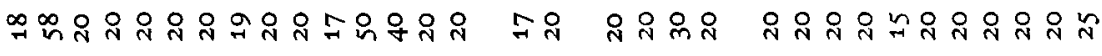

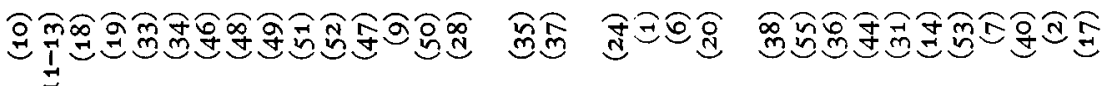
$\Xi$

\{
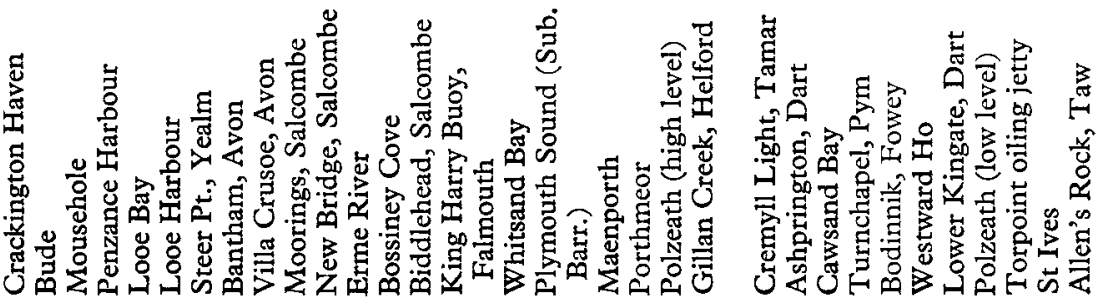


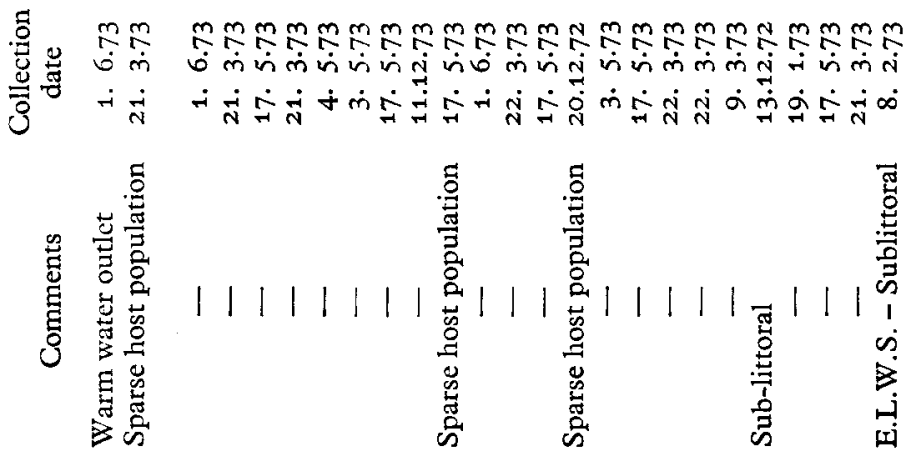

突我 旁

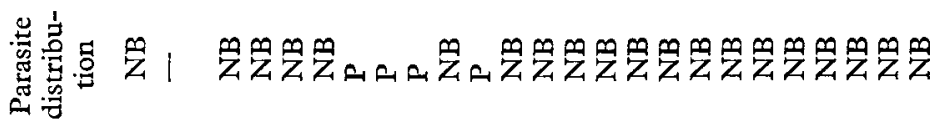

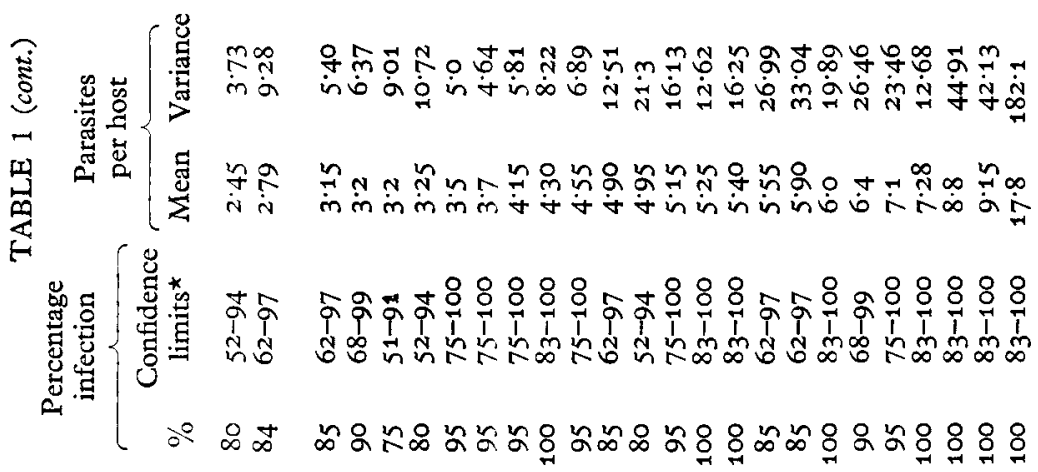

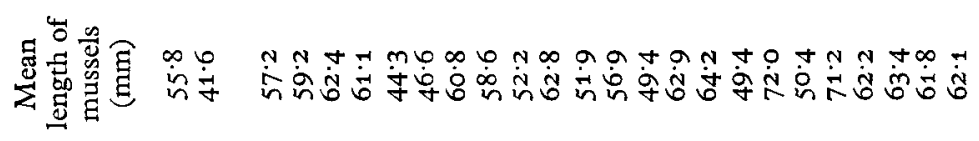

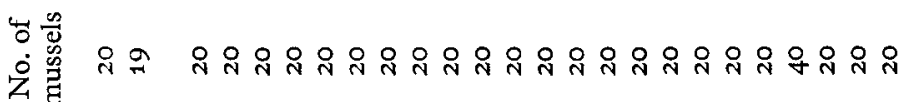

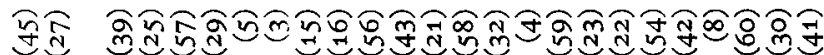

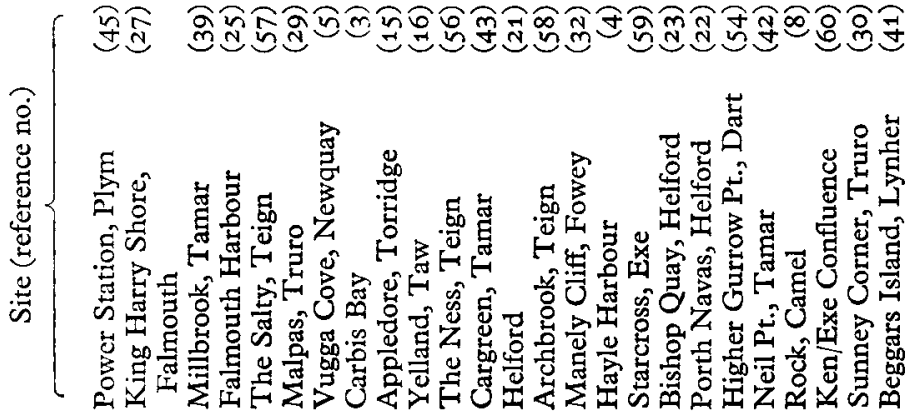




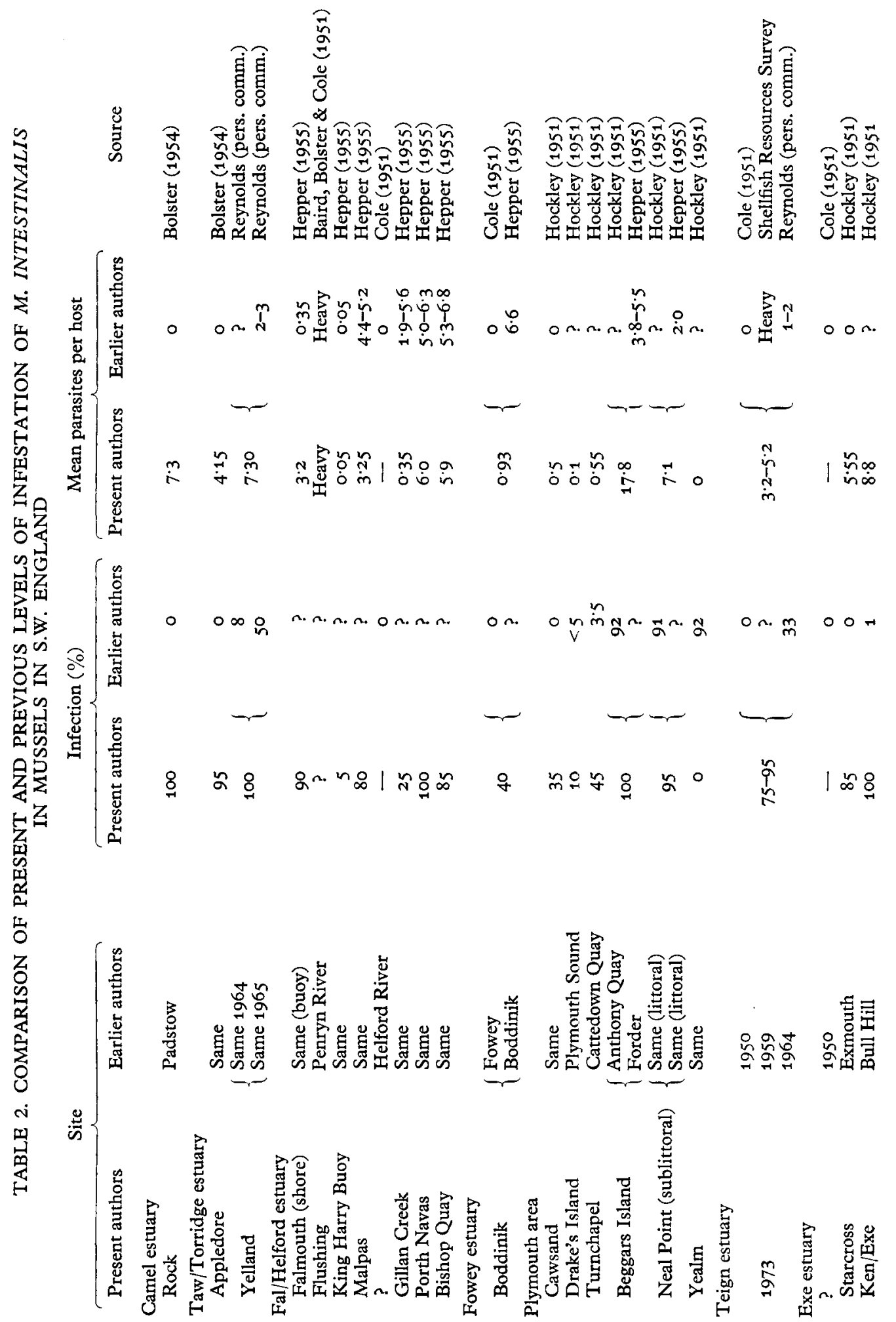




\section{DISCUSSION}

Table 2 shows that in those localities which were moderately or heavily infested 20 years ago there appears to have been little change in either the extent or the intensity of infestation (with the possible exception of the Fowey and the Yealm where we had great difficulty finding mussels at the sites mentioned by Hepper, 1955). This might indicate that mussel populations are capable of carrying moderate or high levels of parasitism without undue deleterious effects. However, this cannot be judged without data on changes in the size or distribution of the infested mussel stocks over the same period. Such data are not generally available.

Two significant changes have taken place since the mid-1950s. The first of these is that Mytilicola has spread to all the major ports and estuaries along the Bristol Channel coast of Devon and Cornwall. This may have started in the early 1960 s and has now increased to the extent that the mussel populations of the Taw, Camel and Hayle estuaries have now attained levels of infestation comparable to those in the estuaries of the English Channel, infested for much longer. On this coast there has been a similar increase in parasite burden in the Exe and Dart estuaries which were uninfested in 1950.

The second major change in Mytilicola distribution is that in the mid-1950s the parasite was almost wholly confined to populations of mussels within the estuaries (a fact which led Grainger (1951) to assume that Mytilicola infested only estuarine mussels). Now, however, many of the exposed coastal populations of mussels adjacent to sources of high infestation are themselves infested (e.g. Whitsand, Cawsand, Maenporth, Porthmeor, Westward Ho) albeit at a relatively low level, even when compared to recently infested estuarine populations of mussels.

Seed (1968) has shown that mussels from estuarine sites are considerably larger than mussels of the same age on open coast sites. The differences in infestation levels, therefore, between mussels from these two types of site may be associated with differences in host size. In Fig. 2 the mean parasites per host is plotted against host size for hosts from estuarine sites. The linear regression $y=0.103 x-0.801$ was calculated using a weighting for sample size and the correlation was significant $(P<0.001 ; r=0.888)$. This increase of parasite burden with size of host is unlikely to represent an accumulation of parasites with increasing age of host because of the short life span of Mytilicola (Williams, 1969). Dethlefsen (1972), discussing a similar correlation, suggests that larger hosts attract more parasites as a result of a higher filtration rate. While host size could contribute to the difference in infestation levels between estuarine and open coast populations of mussels, it is not the only factor involved, as demonstrated by the Porthmeor sample. Here remarkably large mussels were growing on the open coast but had only 0.2 parasites per host while at the nearest estuarine site, in Hayle Harbour, similarly sized mussels had 5.4 parasites per host.

Hockley (1951) showed that mussels growing on vertical surfaces and buoys were less infested than ground bed mussels. This he attributed to the rapid removal of infective larvae from surface waters as a result of the negative phototropism of the copepodites. In Table 1 raised and ground sites are indicated by the letters $R$ and $G$. It will be seen that raised sites almost always had low infestations. Where ground bed mussels are 
present over their whole tidal range, height above low water sometimes has a similar effect on infestation levels. This is illustrated in Fig. 3 for the Lynher River population of mussels (samples from LWST and MTL at Rock, however, did not show a difference). The effect indicated in Fig. 3 is more likely to be due to variations in the time mussels are covered with water (and therefore exposed to infestation) than to the photonegative response of the parasite larvae. The effect of tidal height was eliminated by the sampling procedure wherever possible.
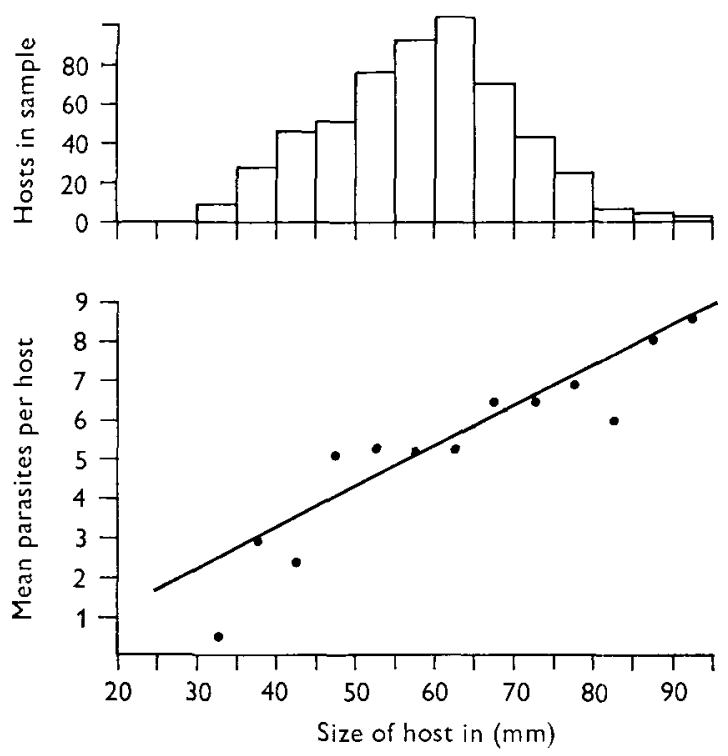

Fig. 2. The relationship between mean number of parasites per host and size of host in samples from sheltered estuarine locations. The histogram shows the number of hosts in each $5 \mathrm{~mm}$ size group.

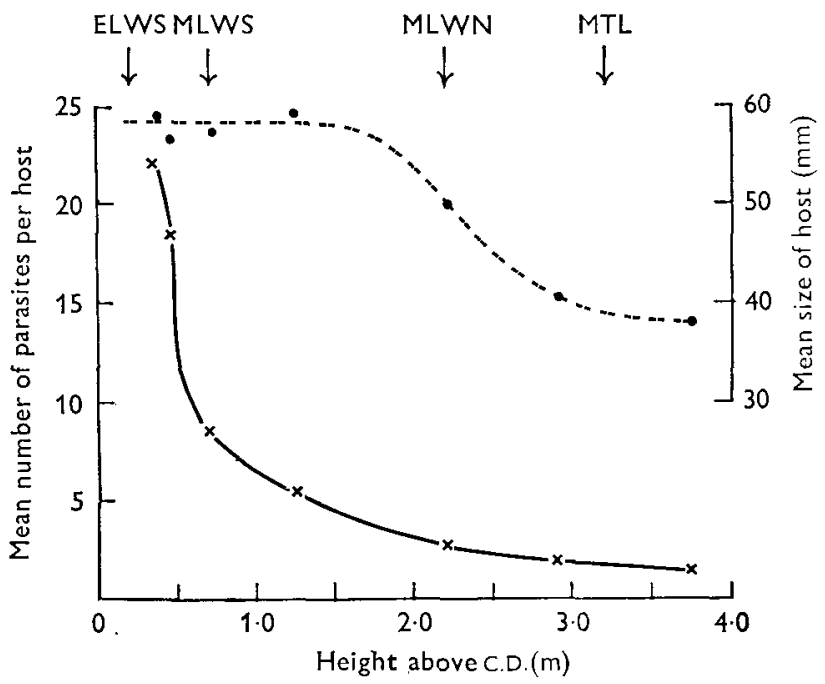

Fig. 3. The mean number of parasites per host (solid line) and mean host size (broken line) in relation to height above Chart Datum at Beggar's Island, Lynher River, in January 1975. 
Bolster (1954), in his discussion of the density of host populations, suggests alternative ways in which this might affect infestation by Mytilicola; on the one hand a high host density might increase the chances of infestation for each copepodite, but on the other hand a low host density might favour the initial establishment of breeding pairs. The chances of the establishment of breeding pairs of parasites, however, depends on the size of the parasite population and on the type of parasite distribution through the host population (which is not necessarily a function of host density). In Table 1 the sites with sparse host populations are indicated; nearly all had light infestations or no parasites

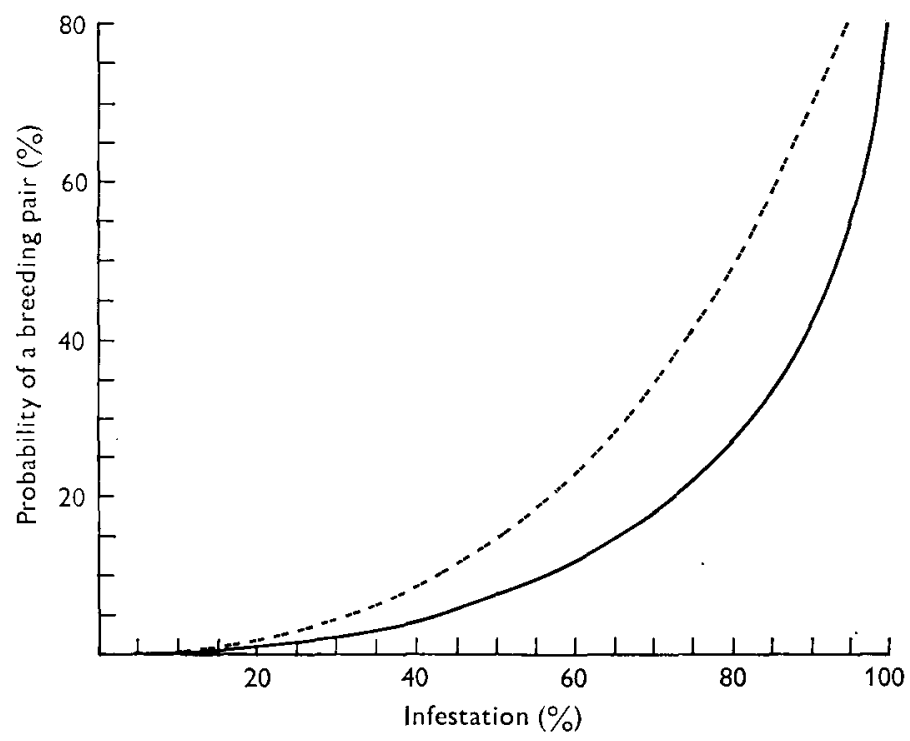

Fig. 4. The relationship between percentage probability of the occurrence of a breeding pair of Mytilicola (based on a male to female sex ratio of 2:1) and percentage infection for a Poisson (solid line) and a negative binomial $(k=1)$ distribution (broken line).

which suggests that the establishment of infestation is difficult where the density of the hosts is low, presumably because the chance of infestation by each copepodite is reduced. It will also be seen from Table 1 that at low percentage infestations the parasites are distributed randomly through the host population whereas over about $60 \%$ infestation a negative binomial distribution is generally indicated (probably generated by a series of random distributions). Fig. 4, based on a parasite male to female sex ratio of $2: 1$, shows that below about $60 \%$ infestation the probability of the occurrence of breeding pairs in a Poisson distribution is only about half that of a negative binomial distribution in which $k=1$.

Hockley (1951) and Bolster (1954) agree with the conclusion that fully marine conditions are not detrimental to Mytilicola. Indeed, it is the low salinity extreme that is most limiting. Table 1 shows that at Carbis Bay and Vugga Cove quite high infestations (3.7 and 3.5 parasites per host) were present in mussels growing in fully marine conditions. Probably the lowest salinity was at Gillan Creek where the infestation level was 0.35 parasites per host. 
Exposure to wave action has been considered detrimental to the parasite and Bolster (1954) suggests that this and high water current speeds might be the most critical physical factors. In Table 1, exposed and sheltered sites are indicated by $\mathrm{E}$ and $\mathrm{S}$ respectively. All the populations of mussels on exposed sites had less than two parasites per host. Populations of mussels in sheltered localities with means of less than two parasites per host either were in raised positions or had a very low density. All the populations with more than two parasites per host were in sheltered localities.

Thus when the factors discussed previously have been taken into account there appears to be a fairly clear inverse relationship between degree of exposure and intensity of infestation. This is most clearly illustrated in the series of samples: Hayle, Carbis Bay, St Ives, Porthmeor. In this series the effects of differences in such factors as tidal height, host size and population density and salinity are minimal, but there is a gradual increase in exposure from Hayle to Porthmeor and a corresponding decrease in parasite burden. Furthermore, mussels from exposed sites at Maenporth and Whitsand are very lightly infested (0.15 and 0.06 parasites per host) despite their proximity to the Fal and the Tamar, sources of very heavy infestation for the last 20 years. In contrast, the new infestations at Vugga Cove, Newquay, a site which is protected by a headland from the exposed conditions prevailing on the Bristol Channel coast, already has a mean burden of 5.0 parasites per host. Bouquet \& Stocks (1957) suggested, and Kleeton (1963) tried to show that a similar relationship to exposure occurred in the case of the copepod parasite Trochicola entericus in Gibbula cinerea, on a small island in Baie de Morlaix. Such a relationship could not be proved conclusively, however, as in this case there was also a marked inverse relationship between exposure and host density.

The authors wish to thank Mrs S. L. Moore for her help in the collection and examination of the material, and Dr L. Pennycuick of the Marine Biological Association for her help with analysis of the parasite frequency distributions. This work forms part of the estuarine ecology programme of the Natural Environment Research Council.

\section{REFERENCES}

Baird, R. H., Bolster, G. C. \& Cole, H. A., 1951. Mytilicola intestinalis in the European flat oyster, Ostrea edulis. Nature, London, 168, 560.

BALlANTINE, W. J., 1961. A biologically-defined exposure scale for the comparative description of rocky shores. Field Studies, 1, 1-19.

Bolster, G. C., 1954. The biology and dispersal of Mytilicola intestinalis Steuer, a copepod parasite of mussels. Fishery Investigations. Ministry of Agriculture, Fisheries and Food, Series 2, 18 (6), $1-30$.

Bouquet, C. \& STock, J. H., 1957. Copépodes parasites d'invertébrés des côtes de France. Travaux de la Station biologique de Roscoff, 8, 223-39.

Cole, H. A., 1951. Le Mytilicola en Angleterre. Revue des traveux de l'Office (scientifique et technique) des pêches maritimes, 17, 56-61.

Cole, H. A. \& SaVAGE, R. E., 1951. The effect of the parasitic copepod Mytilicola intestinalis (Steuer) upon the condition of mussels. Parasitology, 41, 156-61.

Couteaux-Bargeton, M., 1953. Contributions a l'étude de Mytilus edulis L. parasité par Mytilicola intestinalis Steuer. Fournal du Conseil, 19, 80-4.

Crowley, M., 1972. The parasitology of Irish mussels (Mytilus edulis). International Council for the Exploration of the Sea (C.M. Papers and Reports), K: 8, 12 pp. 
DARE, P. J., 1974. A survey of the distribution limits of Mytilicola intestinalis Steuer in England and Wales, 1972-74. International Council for the Exploration of the Sea (C.M. Papers and Reports), K: 12, $12 \mathrm{pp}$.

Dethlefsen, V., 1972. Zur Parasitologie der Miesmuschel (Mytilus edulis L.). Bericht der deutschen wissenschaftlichen Kommission für Meeresforschung, 22, 344-71.

DrINKWATER, J., 1971. Further observations on the distribution of Mytilicola intestinalis around Scotland. International Council for the Exploration of the Sea (C.M. Papers and Reports), $\mathrm{K}: 31,13 \mathrm{pp}$.

Grainger, J. N. R., 1951. Notes on the biology of the copepod Mytilicola intestinalis Steuer. Parasitology, 41, 135-42.

HePper, B. T., 1953. Artificial infection of various molluscs with Mytilicola intestinalis Steuer. Nature, London, 172, 250.

Hepper, B. T., 1955. Environmental factors governing the infection of mussels by Mytilicola intestinalis. Fishery Investigations. Ministry of Agriculture, Fisheries and Food, Series 2, 20 (3), $1-21$.

Hockley, A. R., 1951. On the biology of Mytilicola intestinalis (Steuer). Fournal of the Marine Biological Association of the United Kingdom, 30, 223-32.

KLeEToN, G., 1963. Corrélation entre la fréquence de Trochicola entericus Dollfus 1914, et les conditions du milieu. Proceedings $K$. Nederlandse akademie van wetenschappen (C), 66, 70-3.

Korringa, P., 1951. Le Mytilicola intestinalis Steuer (Copepoda parasitica) menace l'industrie moulière en Zelande. Revue des travaux de l'Office (scientifique et technique) des pêches maritimes, 17, 9-13.

MeYer, P. F. \& MANN, H., 1950. Beiträge zur Epidemiologie und Physiologie der parasitischen Copepoden Mytilicola intestinalis. Archiv für Fischerei-wissenschaft, 2, 120-34.

SEED, R., 1968. Factors influencing shell shape in the mussel Mytilus edulis. Fournal of the Marine Biological Association of the United Kingdom, 48, 561-84.

STEEL, R. G. D. \& TORRIE, J. H., 1960. Principles and procedures of statistics, with special reference to the biological sciences. $479 \mathrm{pp}$. London and New York: McGraw Hill.

WaUGH, G. D., 1954. The occurrence of Mytilicola intestinalis Steuer on the east coast of England. Fournal of Animal Ecology, 23, 364-7.

Williams, C. S., 1969. The life-history of Mytilicola intestinalis Steuer. Fournal du Conseil, 32, 419-28. 